\title{
ВЛИЯНИЕ РАННЕГО НАЧАЛА ПРИЕМА ДУЛАГЛУТИДА НА ГЛИКИРОВАННЫЙ ГЕМОГЛОБИН (А1С) У ПАЦИЕНТОВ С САХАРНЫМ ДИАБЕТОМ 2 ТИПА
}

\author{
'Мередит Хуг, ² Джозеф Смит, 'Мария Ю, 'Дженнифер Пелешок, 'Рима Моди, 'Майкл Грабнер, \\ З Демидова Т. Ю. \\ ${ }^{1}$ «ли Лилли энд Компани» (Eli Lilly and Company), Индианаполис, Индиана \\ ${ }^{2}$ «ХэлсКор Инк.» (HealthCore, Inc.), Уилмингтон, Делавэр \\ з Российский национальный исследовательский медицинский университет им. Н. И. Пирогова, Москва,
}

ЦЕЛЬ: оценить гликемический контроль на протяжении 6 месяцев у пациентов с сахарным диабетом 2 типа (СД2), начавших прием дулаглутида (DU - dulaglutide) в дозе 0,75 или 1,5 мг после использования на протяжении 24 месяцев 1, 2 или 3+ пероральных сахароснижающих препаратов (ПССП).

МАТЕРИАЛЫ И МЕТОДЫ: в данном ретроспективном наблюдательном исследовании использовались записи из базы данных компании «ХэлсКор» США (HIRD ${ }^{\circledR}$ - HealthCore Integrated Research Database), собранные за период с ноября 2012 г. по февраль 2020 г. (момент фиксации первого приема DU с ноября 2014 г. по август 2019 г.). В данное исследование были включены пациенты в возрасте 18 лет и старше с СД2, оставившие 1 и более заявку на ПССП в аптеке в течение всего периода наблюдения до момента фиксации первого приема DU. Период наблюдения в рамках исследования включал 24 месяца до фиксации момента первого приема DU и 6 месяцев после. Пациенты должны были иметь 1 и более результат гликированного гемоглобина (A1C) в течение 6 месяцев как до, так и после момента фиксации первого приема DU.

РЕзУЛЬТАТЫ: среди пациентов, включенных в исследование, наблюдались различия с выраженной тенденцией к увеличению возраста, роста сопутствующей патологии и более высокого исходного уровня А1С в зависимости от количества ранее принимаемых ПССП (1 ПССП [N=761], 2 ПССП [N=1088], 3+ ПССП $[\mathrm{N}=1329])$. Среднее значение исходного уровня $\mathrm{A} 1 \mathrm{C}$ в группах пациентов, принимавших 1, 2 и 3+ ПССП, составило 8,18, 8,56 и 8,73\% соответственно.

Снижение A1C в группе пациентов, принимавших до фиксации момента первого приема DU, 1 ПССП, составило 1,39\%, в группах 2 ПССП и 3+ ПССП снижение А1С составило 1,30 и 1,01 \% соответственно. Более значительное снижение $\mathrm{A} 1 \mathrm{C}$ наблюдалось в подгруппах с более высоким исходным уровнем $\mathrm{A} 1 \mathrm{C}$ в каждой группе по количеству принимаемых ПССП.

ВЫВОдЫ: в данном исследовании в условиях реальной клинической практики было отмечено значимое снижение A1C во всех группах пациентов через 6 месяцев после фиксации момента первого приема DU, с растущей тенденцией к большему снижению A1C в группах пациентов, принимавших исходно меньшее количество ПССП.

ОПУБЛИкОВАНИЕ. Ранее был принят 81-й ежегодной научной сессией Американской диабетической ассоциации (от англ. ADA - American Diabetes Association); дистанционная сессия; 25-29 июня 2021 г.

КЛЮЧЕВЫЕ СЛОВА: дулаглутид; сахарный диабет 2 mипа; пероральные сахароснижающие препараты (ПССП); гликированный гемоглобин (А1С). 